\title{
Realizations of Conceptual Metaphors of ANGER in Arabic, Russian and English: A Contrastive Corpus-Based Approach
}

\author{
Mervat Albufalasa $^{1} \&$ Yulia Vorobeva ${ }^{1}$ \\ ${ }^{1}$ Department of English Language and Literature, University of Bahrain, Kingdom of Bahrain \\ Correspondence: Department of English Language and Literature, University of Bahrain, P. O. Box 32038, \\ Kingdom of Bahrain. E-mail: malbuflasa@uob.edu.bh
}

Received: August 6, 2020

Accepted: September 11, 2020

Online Published: September 23, 2020

doi:10.5539/ijel.v10n6p264

URL: https://doi.org/10.5539/ijel.v10n6p264

\begin{abstract}
Conceptual metaphors are often analyzed out of context. Nevertheless, the crucial role of context is evident as metaphors do not only transmit specific entailment of particular concepts, but they also reflect cultural and social characteristics. At the same time, one cannot deny that conceptualization is involved in the interpretation of various cultural models and conceptual metaphors. The purpose of the current research was to analyze conceptual metaphors of ANGER in Arabic, Russian and English. The current study employed a contrastive corpus-based approach to compare and contrast the conceptual metaphors of ANGER in the aforementioned languages. The outcomes of this research study contributed immensely to the existing literature on conceptual metaphors analysis as there are almost no previous researches done in the field comparing three languages belonging to different language groups. The study found that the Arabic language demonstrated the highest tendency towards conceptual metaphors formation out of the three languages. The study confirmed that cultural context played a significant role in the formation of conceptual metaphors, and it also proved that due to different cultural environments, some metaphors are unique by nature and can be present only in a particular language. It can be concluded that conceptual metaphors of ANGER are not a universal concept, and cultural norms and values make this concept non-identical in the aforementioned languages.
\end{abstract}

Keywords: conceptual metaphors, conceptualization, cultural models, context

\section{Introduction}

There has been a lot of research devoted to the analysis of emotion metaphors in the recent years. Emotion metaphors are examined using conceptual metaphors framework which is adapted from Lakoff and Johnson (1980) as well as Fauconnier and Turner (2002). Lakoff and Turner (1989) propose activation of source and target domains while interpreting conceptual metaphors leaving unnoticed blending of two domains. Cognitive Metaphor Theory interacts with two fixed models while blending theory deals with four basic spaces: traditional source, target domains, generic space (which demonstrates common features of target and source domains) and blended space (where selected features are transferred from target source domains). Nevertheless, Cruse and Croft (2004) highlight that Cognitive Metaphor Theory and Blending Theory structures are "partially responsive to contextual factors" (p. 207) which hinders adequate interpretation of conceptual metaphors. Hence, one of the major drawbacks in interpreting conceptual metaphors is supposed to be context sensitivity as even Blending Theory referring partially to it does not explain 'how features are selected' in the blended space (Croft \& Cruse, 2004).

Emotion metaphors are not an exception, and thus, from this point of view, Constantinou (2014) notices that decontextualization "seems to be a methodological flaw" (p. 159) in the analysis of emotion metaphors in most of current studies as they refer mainly to the analysis of dictionary entries and conventional metaphors as well as decontextualized phrases. It is worth to mention as well that the vast majority of current studies analyze a single language, mainly American English or two. The purpose of the current research is to fill in these gaps as it aims to investigate the conceptual metaphors of ANGER in three corpora: Arabic, Russian and English. In addition, a corpus-based approach enables researchers to project valid and accurate information from source domain of the concept ANGER to its target domain relying on the contextual knowledge as well as delineate how the concept of ANGER is contrasted in the aforementioned communities taking into account social and cultural settings and norms. The analysis of ontological and epistemic correspondences allow to track how meaning is evaluated in 
the interpretation of conceptual metaphors of ANGER stressing correspondences between domains and their elements highlighting encyclopedic knowledge. The current research paper is organized as follows. First, it presents literature review focusing its attention on conceptualization, cultural models, conceptual metaphors and context. Then, it is followed by a methodology implemented for the analysis of conceptual metaphors. The practical part presents the results and elaborations of conceptual metaphors in three sub-corpora. Finally, the study discusses its results in the conclusion.

\section{Literature Review}

\subsection{Conceptualization}

Conceptualization or construal interpretation is related to the cognitive process which creates cognitive concepts. It is the result of the human mind activity and is mainly used to interpret real-world experiences. According to Mischler (2013) people use language expressions to communicate different construals, and with the help of these concepts, human practical knowledge is systematized in the mind. Various researchers delineate conceptualization differently. Croft and Cruse (2004) suggest a detailed classification of construal operations, which embraces four primary cognitive abilities that are used in diverse environments. These cognitive abilities are attention, judgment/comparison (including identity image schema), perspective/situatedness and constitution/ gestalt. Metaphor as a construal operation is incorporated into judgment/comparison category. They view a metaphor in terms of two domains: source and target stressing the relationship between them. Evaluating the exact relationship between two domains has been the subject of discussions in Cognitive Linguistics (Croft \& Cruse, 2004).

Talmy (1988) and Langacker (1987) describe construal operations in the field of Cognitive Semantics. Talmy (1988), for example, presents four type taxonomy named Imaging Systems which includes such topics as structural schematization, deployment of perspective, distribution of attention and force dynamics. Wildgen (1994) notices that Talmy's understanding of semantics deals with searching similarities between spatial awareness and main linguistic schematizations. Talmy's main accents underline the idea of the perceptions in common activities insofar regarding his work as empirical. Wildgen (1994) further observes that a Talmy's theoretical structure might also contain some semantic and perceptual characteristics which is not methodologically developed. At the same time, Langacker (2008) considers that linguistic meaning incorporates both conceptual content and the construal that accompanies it. He suggests using the term domain that characterizes the content. A linguistic sign conjures up a group of cognitive domains that create the platform for the meaning. Domain is supposed to be related to any practical knowledge that a human being acquires. The most crucial aspect in it is to identify a diversified base of the conceptual content which is settled in the language expression (Langacker, 2008).

To finalize the prelude on conceptualization, it is worth to highlight that cognitive conceptualization of meaning (the term offered by Mischler, 2013), is related to non-autonomous knowledge. Mischler refers to Geeraerts (2006), cited in Mischler (2013), who is convinced that linguistic meaning cannot be detached from the knowledge of the social milieu and non-autonomous knowledge is incorporated into human's cognitive abilities. Moreover, various knowledge types are presented in the form of network, which is used for evaluation of every new experience.

\section{Cultural Knowledge, Cultural Models, Cultural Scripts}

Every society initiates its own structure of shared cultural knowledge, which creates an outlook on the basic conceptualizations realized as particular conditions in a certain language (Mischler, 2013). This outlook is presented structurally in the form of conceptual links named as cultural models. Social groups and individuals use cultural models to construe embodied practical knowledge and evaluate the role of practical knowledge in the society. Undoubtedly, conceptualization, which is employed in the construal of practical knowledge and in its verbalization, embraces non-autonomous knowledge arranged as the network of cultural models. Cultural models are present in every society and play a significant role for productive communication (Mischler, 2013). They present cultural knowledge coherently and are considered by various researchers as cognitive systems (Dirven, Yu, \& Niemer, 2008 as cited in Mischler, 2013).

Another approach towards cultural knowledge could be found in Wierzbicka (2010) who develop a theory of cultural scripts where the main claim is related to the idea that in various speech communities there exist various cultural norms and "different ways of speaking prevailing in different societies are linked with, and make sense in terms of, different local cultural values" (p. 47). The primary aim of cultural scripts is to interpret linguistic conventions, social customs and norms in the way as language speakers understand them. The employment of cultural scrips technique testifies that semantic metalanguage (NSM), stemming from universal human concepts, 
can be applied for interpreting cultural language expressions as well as recording cultural scripts being a language user of a particular speech community (Wierzbicka, 2010).

\subsection{Cultural Models and Conceptual Metaphors}

According to Goldberg (2010), Svanlund (2007), Perkins (1992) as cited in Mischler (2013, p. 10), cultural models are employed for interpreting various language phenomena including conceptual metaphor. They differentiate between three typical characteristics for cultural models which are: cognitive organization, structured network of connections and autonomy from other cognitive structure including conceptual metaphor. These features discussed above play a crucial role in the conceptual metaphor organization as well as a production of the linguistic metaphor (Mischler, 2013).

Furthermore, Kövecses (1997) raises the question if a metaphor constitutes or simply reflects cultural models. He claims that cultural models can be traced in abstract and concrete concepts. Any links between cultural models and metaphors can be observed only for abstract concepts as there is no indispensability to interpret concrete concepts. In order to respond to this question, it is important to analyze how abstract concepts emerge. Kövecses (1997) proposes four principles: 1. literal emergence; 2. literal emergence from some basic experience; 3. internally motivated metaphorical emergence; and 4. metaphorical emergence motivated by some external experiential basis (p. 186). Certain abstract concepts are activated via principles three and four (e.g., metaphors). In the third principle, abstract concepts occur from concrete ones through conceptual metaphors where the principle investigates how concept of COMPLEX SYSTEMS works for abstract concepts. In the fourth principle, the concept of MARRIAGE was explored where it does not accord with the Quinn's view who conceives that primary experiences initiate cultural models (e.g., concept of MARRIAGE) and cultural models influence the fitting conceptual metaphors. Kövecses (1997), on the contrary, considers that primary experiences contribute to the fitting conceptual metaphors which initiates cultural models.

Cienki (1999) underpins the premise that metaphorical expressions assist in disclosing cultural models of which they are built in taking into account the difference between "what is being said and assumed cultural knowledge" (p. 201). Metaphorical models, including conceptual metaphors, can introduce various cultural models. He analyzed concepts of PORJADOCHNOST and CHESTNOST in Russian where conceptual metaphors were singled out. The role of metaphors was identified in the analysis of abstract concepts insofar referring to the interrelation between metaphors and cultural models.

Finally, cultural models can be also related to non-linguistic data (a term used by Mischler, 2013). According to Mischler, non-linguistic data is crucial for comprehending cultural values taking into account the impact that culture produces on the semantical meaning of the conceptual metaphor. Lacking non-linguistic data would lead to false construals, in particular how cultural models affect conceptualization in terms of connection between cultural knowledge and cognition.

\subsection{Conceptual Metaphors}

Concepts are defined as the way we perceive the world around us, and thus, our conceptual system is related to everyday life: our thinking, perceptions, feelings, experiences, functions, etc. Conceptual system can be also related to everyday realities; therefore, we tend to perceive those realities automatically/unconsciously as they are parts of our daily life (Lakoff \& Johnson, 1980). Those realities are considered metaphorical in nature, and metaphors are seen as the basis for structuring what and how we perceive, how we think and feel, and what we do. One of the fundamental components of our conceptual system is language as metaphors are expressed by using language; linguistics expressions to reflect on everyday activities, and they are viewed as "a major preoccupation of cognitive linguistics" (Croft \& Alan, 2004, p. 194).

\subsubsection{Definition of a Metaphor}

A metaphor is defined as "understanding and experiencing one kind of thing in terms of another" (Lakoff \& Johnson, 1980, p. 125). It is comparing two different kinds of things for the purpose of structuring, understanding, performing and expressing one concept in relation to another. By doing so, the concept is "metaphorically structured, the activity is structured, and consequently, the language is metaphorically structured" (p. 125). Metaphors are not only a constituent of a literary language as we find them in our everyday language; the literal language, and thus, a metaphor is our understanding of a concept through the use of ordinary words/expressions. These expressions, as explained by Lakoff and Johnson (1980), can be either simple literal expressions or idioms, and they are called "speech formulas" or "fixed-form expressions" or "phrasal lexical items", which function as single words, and are seen as "coherently structure by a single metaphorical concept" to talk about life situations (p. 128). These situations are metaphorically structured, and literal metaphors are 
seen as conventional to "structure the ordinary conceptual system of our culture" that is projected in our daily language (Lakoff \& Johnson, 1980, p. 128).

\subsubsection{How Metaphors Work}

A metaphor involves two domains: source and target (Croft \& Alan, 2004). A source domain refers to "the source of the literal meaning of the metaphorical expression", while a target domain involves "the experience actually being described by the metaphor" (p. 55). The interaction of the two domains are "construed from two regions of purport, and the content of the vehicle domain is an ingredient of the construed target through processes of correspondence and blending" (p. 193). According to cognitive linguists (Croft \& Alan, 2004; Lakoff, 1993; Lakoff \& Turner, 1989; Lakoff \& Johnson, 1980), metaphors are not literally paraphrasable, and that they have a character that no literal expression has.

The argument here is that metaphors do not entail a special kind of meaning as a metaphorical meaning is "the result of a special process for arriving at, or construing, a meaning" (Lakoff \& Johnson, 1980, p. 194). Originally, cognitive linguists argue that metaphorical relations between the two domains at grammatical and semantic levels exist in the human mind and influence the human reasoning and behaviour, and this can be evidently seen through the use of everyday language; conventional linguistic expressions (p. 194). Thus, in this sense, a metaphor empowers language users to organizing their experience and controlling their modes of expression and communication (Constantinou, 2014).

Locative expressions, for instance, can be used metaphorically to describe time and container as discussed by Croft and Alan (2004). They explain that a preposition like 'at', which is locative in nature, can be used to describe time as in I'll come to your office at 9.00. Similarly, We've been in love for three years can make use of the state of love as a container. Lakoff and Johnson's formula of the link between the two domains: target and source, highlights that metaphorical mappings are manifestations of the 'time is space' metaphor and the 'states are containers' metaphor (Lakoff \& Johnson, 1980, pp. 3-32). Lakoff (1993) explains that what constitutes a metaphor is not a particular word or expression: it is rather the "ontological mapping across conceptual dominance" (p. 208) from the source domain to the target domain. He argues that metaphors are not just linguistically recognized, but also and more importantly that are recognized with respect to thought and reason as he points out that the language is considered secondary while the mapping is primary.

This mapping is asymmetrical between the two domains, and this mapping involves epistemic and ontological correspondences (Croft \& Alan, 2004). The ontological correspondences exist between elements of two different domains, whereas epistemic correspondences exist between relations between the elements in the two domains. They also explain that conceptual metaphors are not restricted to "a finite set of linguistic expressions" (p. 197) as further concepts are proposed by Lakoff: metaphorical elaborations and entailments. Metaphors can be further elaborated be carrying over their characteristics from the source domain to the target domain, while entailments provide a set of 'patterns of reasoning' that are also carried over from the source domain to the target domain.

\subsection{Conceptual Metaphors and Context}

Context plays a major role in interpreting metaphors, and that metaphors reflect very specific entailment of particular concepts dominated by a particular culture and past experience (Lakoff \& Johnson, 1980). Different conceptual metaphors are dependent on culture and they vary from one culture to another, and these metaphors can "sanction actions, justify inferences, and help us set goals" that reflect our present reality (p. 130). New metaphorical concepts cause cultural changes which lead to creating new realties overcoming the idea that metaphors are simply language, and replacing it with the idea that metaphors are "means of structuring our conceptual system and the kinds of everyday activities we perform" (p. 132). This is how metaphors are culturally and socially bonded as "what is real for an individual as a member of a culture is a product both of his social reality and of the way in which that shapes his experience of the physical world" (p. 132).

The domains of novel metaphors are construed in context. These construes are influenced by the conational constraints as well as the context (Croft \& Cruse, 2004). Stern (1999) as cited in Croft and Cruse (2004, p. 210) argues that the characteristics of the source and target domains depend heavily on the context of the linguistic expressions and even the whole discourse. He also emphasizes that context influences domains in terms of "what is salient and what is back-grounded, patterns of inference, and expressive or attitudinal factors" (p. 210). There are contextual factors that influence metaphors in context (Kovecses, 2015). These factors can be grouped into four categories: situational, discourse, conceptual cognitive and bodily contexts, which are further broken into smaller units. He also points out the importance of understanding metaphors in context as "contextual factors can motivate, trigger, point, facilitate, shape, etc. the use of a particular metaphor in discourse" (p. 110). He also argues that these categories prime people to choose metaphors in relation to context or discourse. Finally, 
Nünning, Grabes and Baumbach (2009) argue that we should conceptualize metaphors as a 'cultural phenomenon' to enlighten those who are interested in conceptual metaphors to get better insights into the habits, thoughts, and feelings of particular cultures.

\section{Methodology}

For conducting this research, a qualitative method was applied. Authors mainly used data from three corpora: Arabic, Russian and English. Some examples were also extracted from the Internet articles on psychological topics related to anger. It was not only the word ANGER that was analyzed, but also lexemes from the same semantic field such as rage, fury, wrath, etc. were evaluated and their contextual data samples were considered from the aforementioned corpora. Authors also classified conceptual metaphors into ontological and epistemic categories. This approach schematized ontological and epistemic correspondences of the specified conceptual metaphors in three languages. A template containing main findings of the research emphasizing conceptual metaphors of ANGER in three languages was provided to showcase how conceptualization was activated in the analyzed languages.

\section{Practical Part}

Kövecses (1986) proposes two conditions of conceptual metaphor productivity. The first condition is purely lexical where language expressions are capable of verbalizing a conceptual metaphor to a certain degree. Moreover, they also emphasize that language expressions "can elaborate conceptual metaphor" (p. 14). The second condition that makes a conceptual metaphor productive is its ability to transfer some information from the source domain to the target domain. Kövecses calls these carryovers as metaphorical entailments. Human's conceptual schemata contains such entailments and they assist conceptual metaphors in their development. This information is closely connected as well with a cultural context.

The analysis of the conceptual metaphors below is related to its structural part which stresses the idea of correspondences between a source domain and a target domain. According to Kövecses (1986), these correspondences are possible to categorize into two types: ontological and epistemic. Ontological correspondences underline correspondences between entities in the source domain to those in the target domain, while epistemic correspondences emphasize the correspondences between knowledge of the source domain and associated knowledge of the target domain. Further investigation of conceptual metaphors in English, Arabic and Russian follows this pattern suggested by Kövecses (1986).

Kövecses (1986) suggests a list of basic-level metaphors that is devoted to the analysis of the concept of ANGER. This list singles out the following conceptual metaphors:

\section{ANGER IS THE HEAT OF FLUID IN THE CONTAINER}

He was filled with anger.

\section{ANGER IS FIRE}

She was doing a slow burn.

\section{ANGER IS INSANITY}

You are driving me nuts!

ANGER IS AN OPPONENT

He was battling with anger

ANGER IS A DANGEROUS ANIMAL

He has a ferocious temper

\section{CAUSING ANGER IS TRESPASSING}

Get out of here!

\section{THE CAUSE OF ANGER IS A PHYSISCAL ANNOYACE}

Stop bugging me!

You're getting under my skin!

\section{ANGER IS A BURDEN}

After I let out my anger, I felt a sense of release.

ANGER IS A CAPTIVE ANIMAL 
He unleashed his anger.

\section{ANGRY BEHAVIOUR IS AGGRESSIVE ANIMAL BEHAVIOUR}

Don't snarl at me.

\section{ANGER IS A NATURAL FORCE}

It was a stormy meeting.

\section{ANGER IS A SOCIAL SUPRIOR}

His actions were completely governed by anger.

5.1 Analysis of Conceptual Metaphors of ANGER in Russian, Arabic and English

The purpose of this analysis is to shed light on how ANGER is conceptualized in three aforementioned languages. The material for research was extracted from Russian, Arabic and English corpora. There were identified nine conceptual metaphors that all three languages share. They are: ANGER IS HEAT OF FLUID IN A CONTAINER, ANGER IS FIRE, ANGER IS INSANITY, ANGER IS A DANGEROUS ANIMAL, ANGER IS A FLASH, ANGER IS A COLOUR, ANGER IS BLINDNESS, ANGER IS A DESCTRUCTION, and ANGER IS A PLANT. Furthermore, it was found out that some conceptual metaphors are present only in Russian and Arabic, but not in English. They are: ANGER IS A LOSS OF ONE'S SELF and ANGER IS SATAN. At the same time, Arabic corpus demonstrates the presence of metaphors which are characteristic only for Arabic culture, such as ANGER IS INTOXICATION, ANGER IS A SOUND, and ANGER IS A BITTER EMOTION. Let's consider all examples below.

\subsubsection{ANGER IS HEAT OF FLUID IN A CONTAINER}

Here, a person's anger undergoes a stage of extreme irritation. This comparison describes a condition when a person cannot hold his anger anymore. Anger is treated as fluid that is boiling for some time and then reaches its hottest degree when the container explodes making the liquid go out.

\section{Russian}

1. Как ты не понимаешь, что я лопаюсь от злости оттого, что не могу немедленно... приступить к работе.

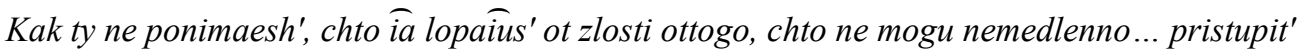
krabote.

[How can't you see that I am bursting with anger just because I cannot perform my duties immediately?! $(\mathrm{RNC})]$

2. У него ведь были все основания для того, чтобы озлобиться, остервениться, последние месяцы своей жизни, находясь под арестом, кипеть злобой и обвинять всех и вся.

U nego ved' byli vse osnovaniia dlia togo, chtoby ozlobit'sia, ostervenit'sia, poslednie mesiatsy svoě zhizni, nakhodias' pod arestom, kipet' zlobou i obviniat' vsekh i vsia.

[Remanding final months of his life in custody, he had all grounds to become angry and even furious, boiling with anger and accusing everyone (RNC)]

\section{Arabic}

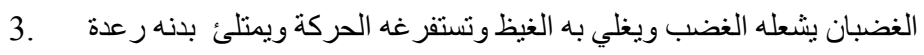

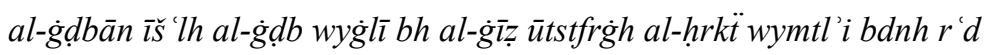

[An angry man is ignited by anger and boiling rage to the extent that it drains his energy and his body is filled with trembling (AC)]

4.

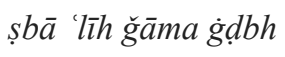

[He poured out his anger on him $(\mathrm{AC})]$

English

5. His anger exploded after it was alleged that he and divorcee Jennifer Fitzgerald, now 59 (BNC). 


\section{Ontological correspondences:}

The body is the container.

The fluid should reach a high temperature to cause anger.

The heat of fluid is capable to explode when it reaches the limit.

Epistemic correspondences:

Source: The fluid is heated in the container to the extent that it makes it boil.

Target: The anger is increased to such an extent that the person is captured by it.

Source: The fluid in the container reached the limit and it exploded.

Target: The person affected by anger is not capable to hold it anymore.

\subsubsection{ANGER IS FIRE}

Anger is compared with fire where different stages of fire burning are contrasted with the condition of a person who is extremely angry. For example, Arabic metaphorical expression 'embers of anger' (example 6) highlights the final stage of fire burning, while the Russian metaphor 'provoke to a white rage' (example 3) describes the utmost state of anger where all emotions pass the limits of endurACe, in particular it is compared with a situation when a metal is burnt to its extreme and becomes look white.

\section{Russian}

1. Голубые глаза... кроткие глаза... А каким могут они пылать гневом! А какой отвагой могут они загораться!..

Golubye glaza... krotkie glaza... A kakim mogut oni pylat' gnevom! A kakoŭ otvagoŭ mogut oni zagorat'sia!...

[These blue eyes... expressing meekness ... And how they can burn with anger! And how courageously they can light up! (RNC).]

2. - Как может нежное сердце женщины распаляться такой злостью?

- Kak mozhet nezhnoe serdțe zhenshchiny raspatiat'sia takǒ zlost'iu?

[- How is that possible that a tender heart of the woman might inflame with anger so heavily? (RNC)].

3. Всё это меня раздражало, нервировало, бесило и доводило до белого каления - но ни в коей мере не удивляло.

Vsë èto menia razdrazhalo, nervirovalo, besilo i dovodilo do belogo kaleniīa - no ni v koeì mere ne udivtialo.

[All these irritated me, made me nervous, infuriated and provoked to be white with rage (RNC).]

\section{Arabic}

4. غضباء ولم أشعل فداك حروبا

$\dot{g} d b \bar{a}^{\prime} \bar{u} l m$ aš $l$ fdāk $h r u \bar{b} \bar{a}$

[In this context, the speaker was agreeing that the addressee was right to be angry with him as he did not "ignite wars for her/his sake" (AC).]

5. با أمة نامت على جمر الغضب "

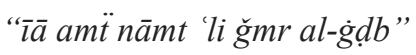

["O nation that slept on the embers of anger" (AC).]

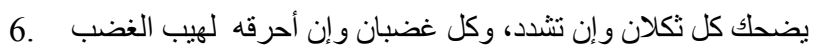

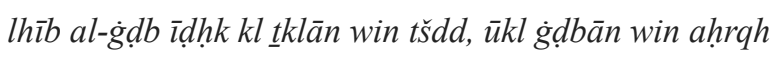

[In this context, two men were arguing and their silly arguments made others laugh at them. Others, here, are defined as those who lost their beloveds and those who were burned by the flames of anger (AC).]

\section{English}

7. And suddenly she felt fierce anger flare up inside her at the way he continually misjudged and denied her and seemed ... (BNC). 


\begin{tabular}{|l|l|}
\hline Source: FIRE & Target: ANGER \\
\hline
\end{tabular}

Ontological correspondences:

The fire is anger.

The strength of the fire is equal to the strength of the anger.

Epistemic correspondences:

Source: Fire can burn intensely for a certain period of time.

Target: A person can be extremely angry for a certain period of time.

Source: Objects when burning intensely, reach their utmost state.

Target: A person who is strongly irritated, reaches limits of his patience.

Source: Objects burn and increase its burning intensity.

Target: A person can be captured by anger as well as intensify it due to some reasons that keep irritating him.

\subsubsection{ANGER IS INSANITY}

Anger can reach its utmost state when the ability to control the emotions is lost and the person is not capable to react adequately. The Arabic metaphor in examples 2 and 3 demonstrates that person's mind is switched off at this state:

\section{Russian}

1. Господи, вспомнить бы еще, что я там вам накорябал?- Сколько мне помнится, Танитриэль пришла в бешеную ярость, когда узнала, что вы .....

Gospodi, vspomnit' by eshche, chto îa tam vam nakoriabal? - Skol'ko mne pomnitsia, Tanitrièl' prishla $v$ beshenuiu iarost', kogda uznala, chto vy .....

[God, I should remember what I scribbled you there. - As far as my memory serves me right, Tanitrielle went into an insane rage when she found out that you ... (RNC).]

\section{Arabic}

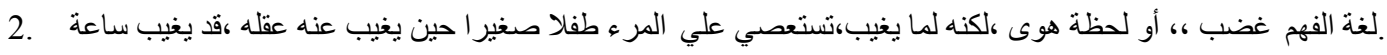

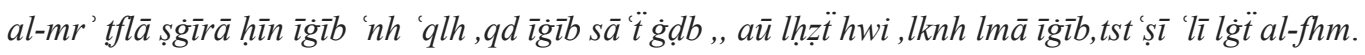

[A man becomes a little child when his mind is gone either by his anger or his passion, and when this happens he cannot comprehend the language of sanity (AC).]

3. الغضب يطفى سر اج العقل

$a l-\dot{g} d \underline{d} b \bar{i} t f i$ ' srāğ $a l-' q l$

[Anger puts off the lamp of the mind (AC).]

\section{English}

4. His eyes seemed to be popping out of his head in uncontrollable anger (BNC).

\begin{tabular}{|l|l|}
\hline Source: INSANITY & Target: ANGER \\
\hline
\end{tabular}

Ontological correspondences:

Uncontrollable behavior is angry behavior.

Epistemic correspondences:

Source: Angriness at it utmost stage might lead to insane rage.

Target: When the person is irritated at it utmost stage, he can go into insane/uncontrollable rage.

\subsubsection{ANGER IS A DANGEROUS ANIMAL}

Anger is often compared with an animalistic behavior and certain features characteristic to a particular species are transferred into the human world. This metaphor stems from a widespread European metaphor PASSIONS ARE BEAST INSIDE A PERSON (Kövecses, 1986). According to this metaphor every person is supposed to hide uncontrollable emotions inside as the part of a human nature has similarities with a behavior of the wild animal. When the beasts go out, the person's behavior reminds the behavior of the wild animal: it is ferocious, aggressive and uncontrollable. 


\section{Russian}

1. “Он мог бы чувства обнаружить,а не щетиниться, как зверь...”

“On mog by chuvstva obnaruzhit', a ne shchetinit'sia, kak zver'...”

["He could understand his feelings and stop bristling like a beast...." (RNC)].

2. - -Спасибо. Звереть дальше уж некуда. Ты на суду был? Нет, не был, но наслышан.

-Spasibo. Zveret' dal'she uzh nekuda. Ty na sudu byl? Net, ne byl, no naslyshan.

[Thanks. It's high time to stop running wild. Did you attend the court meeting? -No, I did not, but I have heard about it (RNC).]

Arabic

3. وجهي إليها و أنا اشعر بضيق ما بعده ضيق، وأنا أخاطبها بغضب لم أستطيع أن ألجمه

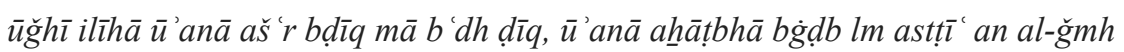

[In this context, the speaker was facing his beloved, feeling upset, he addressed her angrily that he could not curb his anger. Curbing here is associated with horses being restrained (AC).]

4. الترك و الديلم و الأكر اد فعند ذلك برز إليه شركان كأنه أسد غضبان وكان راكبا على ظهر جو اد يشبه شارد

الغزالان النغارد

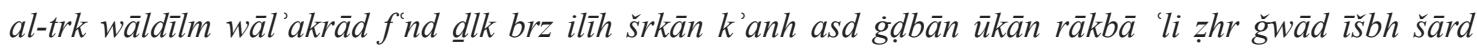
al- $\dot{g} z \bar{a} \bar{a} n$

[In the context of war, three nations (the Turks, Dilem and the Kurds) were involved, and then Sharkhan (the leader) emerged as an angry lion, riding on the back of a horse (AC).]

\section{English}

5. Sir John pushed back his chair, his red face bristling with rage (BNC).

\begin{tabular}{|l|l|}
\hline Source: ANIMAL & Target: ANGER \\
\hline
\end{tabular}

Ontological correspondences:

Aggressive animal is anger.

Epistemic correspondences:

Source: When the animal is unlashed, anger goes out.

Target: When the person cannot control the animal inside him, anger goes out.

\subsubsection{ANGER IS A FLASH}

This metaphor compares anger with a flash that appears suddenly and intermittent. It also demonstrates that the negative emotion that the person unexpectedly has is of high intensity but it does not usually last long.

\section{Russian}

1. И чем больше у него сомнений, тем он может быть жестче и резче. Но чем ярче вспышка гнева, тем он отходчивее ....

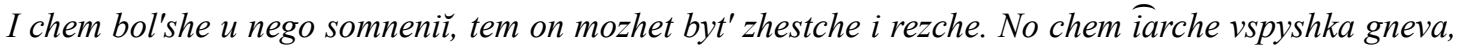
tem on otkhodchivee ...

[And the more he has doubts, the tougher and harsher he can be. But the more intense the flash of anger, the more outgoing he becomes - .....(RNC).]

\section{Arabic}

2. الغضب الساطع آت و إذا كان العالم غير قادر على ضبط المجانين

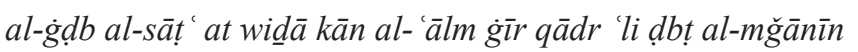

[Bright anger is coming if the world is unable to control the lunatics (AC).]

\section{English}

3. 'I'm sorry, but I can't help you.' Anger flashed in his eyes (BNC).

\begin{tabular}{|l|l} 
Source: FLASH & Target: ANGER
\end{tabular}


Ontological correspondences:

Strong emotions produce blockages that result to anger.

Epistemic correspondences:

Source: Angry state does not last long but it is very intense.

Target: Person's angry state lasts for some time and during this time it is very intense.

\subsubsection{ANGER IS A COLOUR}

This metaphor relates anger with a hot emotion that is red-coloured in all three cultures: Arabic, Russian and English.

\section{Russian}

1. Я увидел там Бернардо, который, красный от злобы......

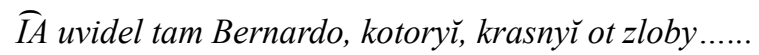

[I saw there Bernardo, who was being red from anger.... (RNC)]

\section{Arabic}

2. العيون الحمر للعرض الدفارق، كعين الغضبان

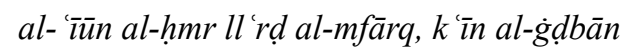

[In this context, even if illnesses are cured, the eyes remain red like the eyes of an angry man (AC).

\section{English}

3. His wife, red spots of anger high on her cheeks, gave him a pithy lecture on the rules of hospitality (BNC).

\begin{tabular}{|l|l|}
\hline Source: COLOUR & Target: ANGER \\
\hline
\end{tabular}

\section{Ontological correspondences:}

Angry state changes person's appearance.

Epistemic correspondences:

Source: Person looks differently when he is very angry.

Target: Person's complexion and other parts of body (i.e. eyes) turn red when he becomes very angry.

\subsubsection{ANGER IS BLINDNESS}

Anger is an emotion that is compared with blindness to showcase that it leads to a complete loss of control, perception and ignorance.

\section{Russian}

1. Спустя какой нибудь час этот слепой гнев превратился в .... Spustia kakŏ nibud' chas ètot slepǒ̀ gnev prevratilsia $v$....

[One hour later this blind anger turned into... (RNC)].

\section{Arabic}

2. الغضب الأعمى

$$
a l-\dot{g} d b a l \text {-' } a \text { 'mi }
$$

[Blind anger $(\mathrm{AC})]$.

\section{English}

3. Half blinded with rage, hardly knowing what she was doing or where she was going... (BNC).

\begin{tabular}{|l|l|}
\hline Source: BLINDNESS & Target: ANGER \\
\hline
\end{tabular}

Ontological correspondences:

Strong emotions cause changes of the original state in human's organism.

Epistemic correspondences:

Source: Angriness leads to blindness in the person's organism. 
Target: Angry state blocks a person emotionally and mentally.

\subsubsection{ANGER IS DESTRUCTION}

Anger is associated with a destructing and demolishing emotion that negatively impacts an individual's state.

\section{Arabic}

1. غضب الصغار انفعالات لا يقى لها أثر و غضب الكبار انفعالات تهدم وتفرق الثمل

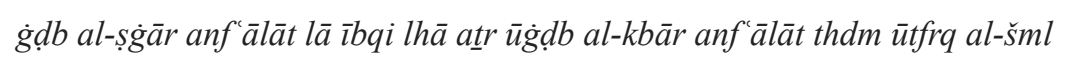

[The anger of very young people are emotions that do not have last and do not have any negative impact, while the anger of adults have emotions that demolish and disperse reunion (AC)].

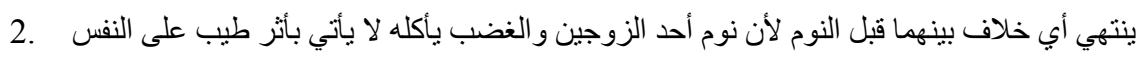

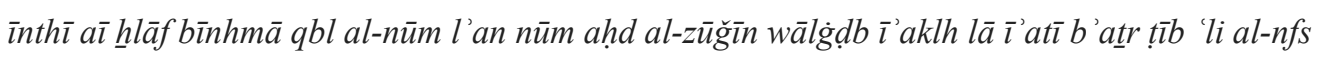

[Any disagreement between spouses ends before going to sleep because sleeping while anger eats him/her up does not have a good effect on oneself (AC)].

English

3. First, that anger is not necessarily destructive (BNC).

\section{Russian}

4. Погружаясь с головой в разрушительный гнев, вы думаете, что у вас просто нет другого выбора...

Pogruzhaias's golovǒ v razrushitel'nyı̆ gnev, vy dumaete, chto u vas prosto net drugogo vybora...

[Delving into the destructive anger, you think that you there are no other options than...].

\begin{tabular}{|l|l|}
\hline Source: DESTRUCTION & Target: ANGER \\
\hline Ontological correspondences: &
\end{tabular}

Ontological correspondences:

Anger is a negative emotion that is capable to destroy inner state.

Epistemic correspondences:

Source: Anger is destructive and devastating.

Target: Person's anger is destructive for him.

\subsubsection{ANGER IS A PLANT}

Here, anger is compared with a growing plant where its different parts as well as growing process describe various stages of anger. Angriness can grow as a plant as well as it can have its source, i.e. 'the root of angriness'.

\section{Russian}

1. Но корень зла лежал именно в статусе судей.

No koren'zla lezhal imenno $v$ statuse suder.

[But the root of angriness lies in the judges' status (RNC)].

\section{Arabic}

2. سنابل الغضب

snābl al-g̣̣db

[Wheat spikes of rage - wheat spikes are known for their height, so rage grows up so high like the wheat spikes $(\mathrm{AC})]$.

3. قذائف عناقيد الغضب تسقط على أهداف مدنية

$q \underline{d} \bar{a}$ 'if 'nāqìd al-ğg̣b tsqt 'li ahdāf mdnï̈

[Grapes of wrath land on civilian targets (AC)].

English

4. Her anger and resentment grew as she drove home and for the rest of that evening she .... (BNC). 


\begin{tabular}{|l|l|}
\hline Source: GROWING PLANT & Target: ANGER \\
\hline
\end{tabular}

Ontological correspondences:

Angriness can develop and grow.

Epistemic correspondences:

Source: Angry state is capable to enhance.

Target: Person's angry state is not static.

\subsection{Conceptual Metaphor of ANGER in Russian and Arabic}

A group of conceptual metaphors that are characteristic only for Arabic and Russian was identified. They are: ANGER IS SATAN, ANGER IS A LOSS OF ONE'S SELF.

\subsubsection{ANGER IS SATAN}

Satan is perceived as an entity that has an evil nature and as a result, this quality is inherited by metaphors below which describe a high stage of angriness that is opposed to adequate human's behaviour.

\section{Russian}

1. Я знаю, от меня тоже можно осатанеть.

$\widehat{I A}$ znaîu, ot menia tozhe mozhno osatanet'.

[I know that you can get satanic from my behavior (RNC)].

\section{Arabic}

2. فالغضب ثغرة، ولذا قال عليه الصلاة والسلام: إن الغضب من الثيطان

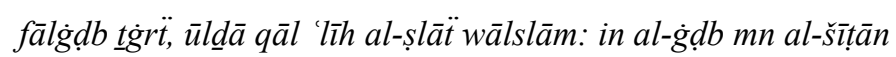

[Anger has a loophole, so he said peace be upon him: "Anger is from Satan" (AC)].

\begin{tabular}{|l|l|}
\hline Source: SATAN & Target: ANGER \\
\hline
\end{tabular}

Ontological correspondences:

Satan is an entity that is treated negatively in Abrahamic religions.

Epistemic correspondences:

Source: Person is influenced by Satan when he is angry.

Target: Person's angriness is inherited from Satan and reaches its utmost stage.

\subsubsection{ANGER IS A LOSS OF ONE'S SELF}

This metaphor describes the state of anger that makes the person lose his temper and feel crushed by a strong emotion that he is holding at the moment. In Arabic the idea of controlling one's self is emphasized when the person is angry.

\section{Russian}

1. - Владимир Игнатьевич, перестаньте!..- воскликнула она, вне себя от гнева. Никто не вступился за бедняжку...

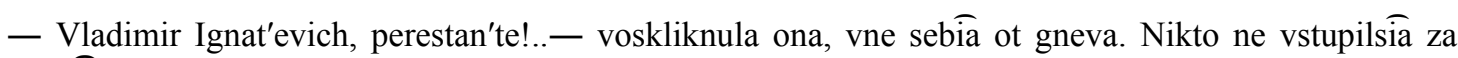
bedniazhku...

[-Vladimir Ignatievich, stop it!- she exclaimed, losing her temper (literally: losing herself). No one gave sympathy to the poor lamb...(RNC).]

\section{Arabic}

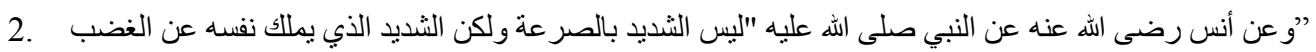

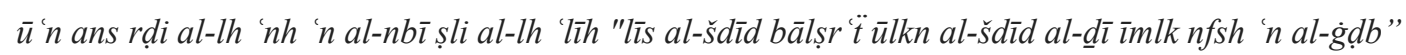

[Anas, may Allah be pleased with him, said that the Prophet (peace and blessings of Allaah be upon him) said that to be strength is not achieved by nervously fighting but by controlling one's self when angry. Thus, if one cannot control their anger, it is related to the loss of self-control (AC)].

\begin{tabular}{|l|l}
\hline Source: LOSS OF SELF & Target: ANGER
\end{tabular}


Ontological correspondences:

Angry state changes person's personality.

Epistemic correspondences:

Source: Temper is lost when the person is very angry.

Target: Person's temper is lost when he becomes very angry.

\subsection{Conceptual Metaphor of ANGER in Arabic}

There is another group of metaphors that was singled out from Arabic corpus and was identified neither in Russian nor in English. They are: ANGER IS A SOUND, ANGER IS INTOXICATION, and ANGER IS EMOTION.

\subsubsection{ANGER IS A SOUND}

This metaphoric meaning implies the idea that anger is a strong negative emotion that can be perceived as something that changes initial person's state as if alerting him by various sounds that initiate anger or, on the contrary, demonstrate its final stage.

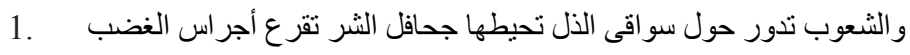

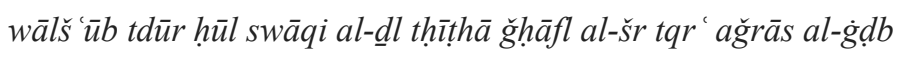

[Peoples revolve around the drivers of humiliation, surrounded by hordes of evil, ringing the bells of anger $(\mathrm{AC})]$.

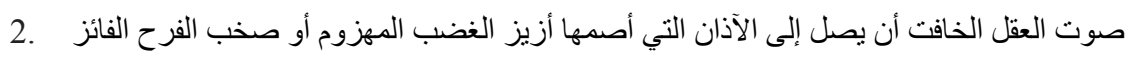

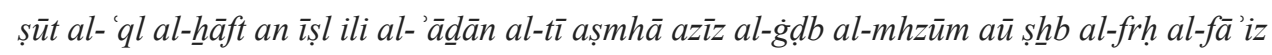

[The faint voice of the mind reaches the ears that are deafened by the buzz of defeated anger or the joy of winning. Buzz could be related here to the sound of fighter jets (AC)].

\begin{tabular}{|l|l|}
\hline Source: SOUND & Target: ANGER \\
\hline
\end{tabular}

Ontological correspondences:

Sound can lead to anxiety and irritation.

Epistemic correspondences:

Source: Angry state is affected by sounds and noises.

Target: Person's angry state at is caused by various sounds and noises.

\subsubsection{ANGER IS INTOXICATION}

Another negative aspect of anger stresses the condition when a person is befuddled by a poisoning emotion.

1. على أن العقل إذا تخلص من سكر الغضب أصابه ما يصيب المخمور

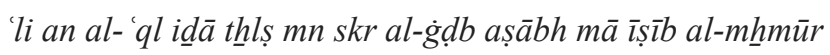

[... the mind gets rid of the drunken anger, it is affected by what a drunken person goes through (AC)].

\begin{tabular}{|l|l|}
\hline Source: INTOXICATION & Target: ANGER \\
\hline
\end{tabular}

Ontological correspondences:

Angriness is a toxic feeling.

Epistemic correspondences:

Source: Angry state provokes loss of control and leads to a deviating state.

Target: Angriness intoxicates person's normal state.

\subsubsection{ANGER IS A BITTER EMOTION}

This unique conceptual metaphor demonstrates that fact that anger can cause even tears in Arabic cultural environment, which is opposed to Russian and English metaphor 'tears of joy'.

1. شمعة ووردة ودموع الغضب

šm $\ddot{t}$ wurd $\ddot{t} \bar{u} d m \bar{u}$ ' al-g̣̣ $d b$

[Candle, rose and tears of anger (AC)]. 


\begin{tabular}{|c|c|c|c|}
\hline \multicolumn{2}{|l|}{ Source: BITTER EMOTION } & \multicolumn{2}{|c|}{ Target: ANGER } \\
\hline \multicolumn{4}{|l|}{ Ontological correspondences: } \\
\hline \multicolumn{4}{|l|}{ Angriness leads to bitter feelings. } \\
\hline \multicolumn{4}{|l|}{ Epistemic correspondences: } \\
\hline \multicolumn{4}{|l|}{ Source: Angriness causes tears. } \\
\hline \multicolumn{4}{|l|}{ Target: Person's angriness provokes his tears. } \\
\hline \multicolumn{4}{|l|}{ 6. Conclusion } \\
\hline \multicolumn{4}{|c|}{$\begin{array}{l}\text { The purpose of the research was to identify the conceptual metaphors of ANGER in three languages ( } \\
\text { Arabic and English) as well as to observe their cultural similarities/differences in the analyzed language } \\
\text { conceptual metaphors of ANGER are summarized in Table } 1 .\end{array}$} \\
\hline \multicolumn{4}{|c|}{ Table 1. Summary of conceptual metaphors of ANGER in three languages } \\
\hline Examples: & English & Russian & Arabic \\
\hline 1. ANGER IS HEAT OF FLUID IN A CONTAINER & $\sqrt{ }$ & $\sqrt{ }$ & $\sqrt{ }$ \\
\hline 2. ANGER IS FIRE & $\sqrt{ }$ & $\sqrt{ }$ & $\sqrt{ }$ \\
\hline 3. ANGER IS INSANITY & $\sqrt{ }$ & $\sqrt{ }$ & $\sqrt{ }$ \\
\hline 4. ANGER IS A DANGEROUS ANIMAL & $\sqrt{ }$ & $\sqrt{ }$ & $\sqrt{ }$ \\
\hline 5. ANGER IS A FLASH & $\sqrt{ }$ & $\sqrt{ }$ & $\sqrt{ }$ \\
\hline 6. ANGER IS A COLOUR & $\sqrt{ }$ & $\sqrt{ }$ & $\sqrt{ }$ \\
\hline 7. ANGER IS BLINDNESS & $\sqrt{ }$ & $\sqrt{ }$ & $\sqrt{ }$ \\
\hline 8. ANGER IS A DESCTRUCTION & $\sqrt{ }$ & $\sqrt{ }$ & $\sqrt{ }$ \\
\hline 9. ANGER IS A GROWING PLANT & $\sqrt{ }$ & $\sqrt{ }$ & $\sqrt{ }$ \\
\hline 10. ANGER IS A LOSS OF ONE'S SELF & & $\sqrt{ }$ & $\sqrt{ }$ \\
\hline 11. ANGER IS SATAN & & $\sqrt{ }$ & $\sqrt{ }$ \\
\hline 12. ANGER IS INTOXICATION & & & $\sqrt{ }$ \\
\hline 13. ANGER IS A SOUND & & & $\sqrt{ }$ \\
\hline 14. ANGER IS A BITTER EMOTION & & & $\sqrt{ }$ \\
\hline
\end{tabular}

In the above table, it is found that metaphors from 1 to 9 are present in all three languages, metaphors from 10 to 11 are identified in Arabic and Russian and metaphors from 12 to 14 are characteristic only for the Arabic language. The results confirm that Arabic corpus tends to demonstrate the highest tendency towards metaphoric language than English and Russian. The research does not stress exact amount of conceptual metaphors in analyzed languages, thus more empirical research is needed on this topic. It is confirmed that cognitive model of anger that is typical for English is shared with Russian and Arabic cultural environment as well. The study also highlights the significant role of the discursive perspective in the interpretation of conceptual metaphors as well as the cultural context in particular where metaphorical expressions disclose cultural models of which they are a part of. The research supports the idea of Basso (1976) that 'language and culture come together and display their fundamental inseparability'.

The conducted research goes with the thesis expressed by Kövecses (1998) that anger as an emotion that presents "elaborate cognitive structure" (p. 36). At the same time, it supports his idea that cognitive model of anger in English is "anything but universal" (Kövecses, 1986: 36). Despite the fact that a vast majority of metaphors analyzed in the research are present in all three languages, at the same time it is demonstrated that there are some unique metaphors of ANGER in Arabic corpus that are absent in Russian and English. Furthermore, the research goes in agreement with ideas of Wierzbicka (2010) on the role of cultural scripts that can be applied in interpreting cultural norms and values that are embedded in various languages. This idea proves the fact that cognitive models vary from one culture to another and cognitive model of ANGER is not an exception.

\section{References}

ArabiCorpus. (n.d.). Retrieved from http://arabicorpus.byu.edu/search.php

Basso, K. (1976). Wise Words of the Western Apache: Metaphor and Semantic Theory. In K. Basso \& H. Selby (Eds.), Meaning in Anthropology (pp. 93-121). Albuquerque: University of New Mexico Press.

British National Corpus. (n.d.). Retrieved from https://www.english-corpora.org/bnc/

Chenki, A. (1999). Metaphors and cultural models as profiles and bases. In Jr. Raymond, W. Gibbs \& J. S. 
Gerard (Eds.), Metaphor in Cognitive Linguistics: Selected papers from the 5th International Cognitive Linguistics Conference, Amsterdam (pp. 189-203). Amsterdam/Philadelphia: John Benjamins Publishing Company. https://doi.org/10.1075/cilt.175.11cie

Constantinou, M. (2014). Conceptual metaphors of anger in popularized scientific texts: A contrastive (English/Greek/French) cognitive-discursive approach. In F. Baider \& G. Cislaru (Eds.), Linguistic Approaches to Emotions in Context (pp. 159-188) Benjamins, Amsterdam. https://doi.org/10.1075/pbns.241.10con

Croft, W., \& Cruse, A. (2004). Cognitive Linguistics. Cambridge: Cambridge University Press. https://doi.org/10.1017/CBO9780511803864

Elle. (n.d.). https://www.elle.ru/otnosheniya/psikho/ne-ori-na-menya-ili-kak-menshe-zlitsya-id6758031/

Fauconnier, G., \& Turner, M. (2002). The way we think. Conceptual thinking and the mind's hidden complexities. New York: Basic Books.

Kövecses, Z. (1986). Metaphors of Anger, Pride and Love: A lexical approach to the structure of concepts. Amsterdam/Philadelphia: John Benjamins Publishing Company. https://doi.org/10.1075/pb.vii.8

Kövecses, Z. (1997). Metaphor. Does it constitute or reflect cultural models? In Jr. Raymond, W. Gibbs \& J. S. Gerard (Eds.), Metaphor in Cognitive Linguistics: Selected papers from the 5th International Cognitive Linguistics Conference, Amsterdam (pp. 167-188). Amsterdam: John Benjamins Publishing House. https://doi.org/10.1075/cilt.175.10kov

Kövecses, Z. (2011). Methodological issues in conceptual metaphor theory. In H.-J. Schmid \& S. Handl (Eds.), Windows to the Mind: Metaphor, Metonymy and Conceptual Blending (pp. 23-39). Berlin/Boston: De Gruyter. https://doi.org/10.1515/9783110238198.23

Kövecses, Z. (2015). How does context produce metaphors? A contextualist view of conceptual metaphor theory. In J. Daems et al. (Eds.), Change of Paradigms-new Paradoxes: Recontextualizing Language and Linguistics (pp. 109-115). Berlin/Boston: De Gruyter.

Lakoff, G. (1993). The contemporary theory of metaphor. In A. Ortony (Ed.), Metaphor and thought (pp. 202-251). Cambridge: Cambridge University Press. https://doi.org/10.1017/CBO9781139173865.013

Lakoff, G., \& Johnson, M. (1980). Metaphors we live by. Chicago: The University of Chicago Press.

Lakoff, G., \& Turner, M. (1989). More than cool reason: A field guide to poetic metaphor. Chicago: University of Chicago Press. https://doi.org/10.7208/chicago/9780226470986.001.0001

Langacker, R. W. (2008). Cognitive Grammar: A basic Introduction. New York: Oxford University Press. https://doi.org/10.1093/acprof:oso/9780195331967.001.0001

Mischler, I. J. III. (2013). Metaphor across time and conceptual space. The interplay of embodiment and cultural models. Amsterdam/Philadelphia: John Benjamins Publishing Company. https://doi.org/10.1075/clscc.3

Nünning, A., Grabes, H., \& Baumbach, S. (2009). Introduction: Metaphors as a way of worldmaking, or: Where metaphors and culture meet. In H. Grabes, A. Nünning \& S. Baumbach (Eds.), Metaphors shaping culture and theory (pp. 11-25). Tübingen: Gunter Narr Verlag.

Russian National Corpus. (n.d.). Retrieved from http://ruscorpora.ru/old/en/index.html

Talmy, L. (1988). Force Dynamics in Language and Cognition. Cognitive Science, 12, 49-100. https://doi.org/10.1207/s15516709 $\operatorname{cog} 1201 \_2$

Wierzbicka, A. (2010). Cultural scripts and intercultural communication. In A. Trosborg (Ed.), Pragmatics across Language and Cultures (pp. 43-78). Berlin/Boston: De Gruyter.

Wildgen, W. (1994). Process, Image and Meaning: A realistic Model of the Meaning of the Sentences and Narrative texts. Amsterdam/Philadelphia: John Benjamins Publishing Company. https://doi.org/10.1075/pbns.31

\section{Copyrights}

Copyright for this article is retained by the author, with first publication rights granted to the journal.

This is an open-access article distributed under the terms and conditions of the Creative Commons Attribution license (http://creativecommons.org/licenses/by/4.0/). 